\title{
Penerapan representasi visual menggunakan komik sebagai upaya meningkatkan kemampuan berpikir kritis dan penguasaan konsep siswa pada materi sistem saraf (The implementation of visual representation using comic as an effort to improve student critical thinking skills and mastery of concepts at nerve systems subject)
}

\author{
Nisrina Nur Rahmi*, Widi Purwianingsih, Siti Sriyati \\ Departemen Pendidikan Biologi FPMIPA Universitas Pendidikan Indonesia, Jl. Dr. Setiabudhi No. 229 Bandung \\ *Corresponding author: nisrinanurrahmi1223@gmail.com
}

Received: 1 August 2021 - Accepted: 1 September 2021 - Published: 30 September 2021

\begin{abstract}
The purposes of this research were to analyze the application of visual representations using comics as an effort to improve student's critical thinking skills and mastery of concepts in nervous system material. The subject of this study is second grade-students in Senior High School. The method used in this research is Quasi experimental. The results of student's critical thinking skills have increased higher in the experimental class, although the results of the critical thinking skills of the two classes are in the moderate category, the results of critical thinking in the experimental class showed that the increase in $\mathrm{N}$ gain was higher with $\mathrm{N}$-gain $=0.64$ (medium category) while $\mathrm{N}$-gain in the control class $=0.53$ (medium category). The results mastery of concepts in experimental class have $\mathrm{N}$-gain is higher the $\mathrm{N}$-gain control class with $\mathrm{N}$-gain is 0.71 (high category), and the control class $\mathrm{N}$-gain is 0.53 (medium category). The results of student responses showed that the majority of students were interested in using comic visual representations of $83.33 \%$. Therefore it can be concluded that the use of comics can improve thinking skills and mastery of concepts better.
\end{abstract}

Keywords critical thinking, mastery of concepts, visual comic representation

\begin{abstract}
ABSTRAK Penelitian ini bertujuan untuk menganalisis penerapan representasi visual menggunakan komik sebagai upaya meningkatkan kemampuan berpikir kritis dan penguasaan konsep siswa pada materi sistem saraf. Subjek dari penelitian ini adalah siswa kelas XI Sekolah Menengah Atas. Metode yang digunakan dalam penelitian ini adalah Quasi experimental. Hasil berpikir kritis siswa mengalami peningkatan lebih tinggi pada kelas eksperimen, meskipun hasil berpikir kritis kedua kelas termasuk dalam kategori sedang, namun hasil berpikir kritis kelas eksperimen menunjukan peningkatan N-gain lebih tinggi yaitu dengan $\mathrm{N}$-gain $=0,64$ (sedang) sedangkan $\mathrm{N}$-gain kelas kontrol $=0,53$ (sedang). Pada hasil penguasan konsep kelas eksperimen menunjukan peningkatan $\mathrm{N}$-gain lebih tinggi dibandingkan kelas kontrol yaitu $\mathrm{N}$-gain $=0,71$ (tinggi), sedangkan kelas kontrol $\mathrm{N}$-gain $=0,53$ (sedang). Hasil respon siswa menunjukan bahwa hampir seluruh siswa tertarik dalam menggunakan representasi visual komik sebesar 83,33\%. Dapat disimpulkan bahwa penggunaan komik dapat meningkatkan kemampuan berpikir kritis dan penguasaan konsep yang lebih baik pada siswa.
\end{abstract}

Kata kunci berpikir kritis, penguasaan konsep, representasi visual komik

\section{PENDAHULUAN}

Pendidikan tidak hanya menekankan pengetahuan konsep saja, tetapi penguatan karakter setiap peserta didik tidak kalah penting. Penguatan pendidikan karakter adalah gerakan pendidikan di sekolah untuk memperkuat karakter siswa melalui harmonisasi olah hati (etik), olah rasa (estetika), olah pikir (literasi) dan olah raga (kinestetik) dengan dukungan pelibatan publik dan kerja sama antara sekolah, keluarga, dan masyarakat (Kemendikbud, 2017).

Hal ini sesuai dengan empat kompetensi yang harus dimiliki siswa di abad 21 yang disebut 4C, yaitu berpikir kritis dan menyelesaikan masalah (Critical Thinking and Problem Solving), kreativitas (Creativity), kemampuan berkomunikasi (Communication Skills), dan kemampuan untuk bekerja sama (Ability to Work Collaboratively) (Fridanianti, Purwati, \& Murtianto, 2018).
Salah satu dari keterampilan abad 21 yaitu keterampilan berpikir kritis. Keterampilan berpikir kritis ini merupakan keterampilan untuk melakukan berbagai analisis, penilaian, evaluasi, rekonstruksi, pengambilan keputusan yang mengarah pada tindakan yang rasional dan logis (King, F.J., Goodson, L., M.S. \& F., 2010). Untuk menerapkan dan meningkatkan keterampilan berpikir kritis siswa di sekolah dapat dilakukan dengan membaca. Menurut Tiemensma (2009) membaca adalah komponen terpenting di abad 21 agar bisa bertahan di era globalisme saat ini. Kemampuan membaca siswa menentukan keberhasilan kegiatan belajar mengajar. Sebagaimana diketahui bahwa sebagian besar pengetahuan disajikan dalam bentuk bahasa tulis sehingga menuntut anak harus melakukan aktivitas membaca guna memperoleh pengetahuan.

Tetapi dilihat dari kemajuan global dan teknologi sekarang, membaca buku sangat susah bagi siswa di 
bandingkan dengan melihat secara visual. Komik menjadi alternatif sumber belajar visual untuk meningkatkan penguasaan konsep dan berpikir kritis siswa. Menurut Mardiyah \& Surakusuma (2016) komik memiliki keunggulan yang dapat meningkatkan semangat belajar siswa karena karakter komik yang lucu dan bervariatif, selain itu dengan komik materi akan mudah dipahami dan memberikana kesan pada siswa sehingga hasil belajar siswa akan mengalami peningkatan karena siswa akan mudah mengingat materi pelajaran.

Pada pelajaran sistem saraf banyak terjadi miskonsepsi. Penelitian yang dilakukan oleh Rahayu (2016) menunjukkan bahwa pada peserta didik SMA mengalami miskonsepsi pada materi sistem saraf. Miskonsepsi pada materi sistem saraf secara keseluruhan yaitu sebesar 25.47\%. Pada sub materi mekanisme impuls saraf mengalami miskonsepsi sebesar $4.37 \%$ dengan persentase jumlah peserta didik yang tidak paham paling tinggi dibanding sub materi lain yaitu sebesar 8.26\%.

Berkaitan dengan uraian permasalahan di atas, maka perlu adanya suatu pemecahan baik terhadap sumber belajar siswa agar proses siswa memahami materi berlangsung dengan baik dengan pembelajaran secara online. Oleh karena itu perlu dilakukan langkah-langkah atau suatu alternatif dalam mengoptimalkan pembelajaran biologi, salah satunya dengan menggunakan sumber belajar berupa komik, sebagai sumber belajar dengan harapan agar kemampuan berpikir kritis dan pengetahuan konsep peserta didik dapat menjadi lebih baik.

Sehubung dengan latar belakang tersebut, maka dilakukan penelitian tentang "Penerapan Representasi Visual Menggunakan Komik Sebagai Upaya Meningkatkan Kemampuan Berpikir Kritis Dan Penguasaan Konsep Siswa Pada Materi Sistem Saraf'.

\section{METODE}

Pada penelitian ini digunakan metode penelitian eksperimen semu (quasi experimental). Quasi experimental menggunakan kelas kontrol namun tidak dapat berfungsi sepenuhnya karena tidak semua variabel bisa dikontrol (Sugiyono, 2014). Desain penelitian yang digunakan adalah Non-equivalent control group design. Desain penelitian ini yaitu satu kelompok subjek diberi perlakuan tertentu (eksperimen) dengan menggunakan sumber belajar komik, sedangkan kelas kontrol dengan menggunakan power point.

Penelitian ini dilakukan di Sekolah Menengah Atas (SMA) di Kota Bandung dengan teknik pengambilan sampel menggunakan convenience sampling dan semua siswa dianggap memiliki karakteristik yang sama.

Instrumen yang digunakan dalam penelitian ini adalah menggunakan tes tertulis essai untuk melihat kemampuan berpikir kritis siswa, tes soal pilihan ganda untuk melihat penguasaan konsep, dan angket respon siswa.

Analisis data yang digunakan dalam penelitian ini adalah analisis statistika deskriptif, uji normalitas, uji homogenitas, uji hipotesis, Uji N-gain, dan analisis angket respon siswa menggunakan skala 1-5.

\section{HASIL DAN PEMBAHASAN}

\section{Tahapan Pembuatan Komik}

Pembuatan komik sebagai sumber belajar melalui tahap pendefinisian (define), tahap perancangan (design), tahap pengembangan (develop) (Witanta \& Inganah, 2019).

Pada tahap pendefinisian (define) dilakukan dengan menganalisis tujuan pembelajaran, berdasarkan kurikulum 2013 dengan Kompetensi dasar 3.10 yaitu menganalisis hubungan antara struktur jaringan penyusun organ pada sistem koordiasi (saraf, hormone dan alat indera) dalam kaitannya dengan mekanisme koordinasi dan regulasi serta gangguan fungsi yang dapat terjadi pada sistem koordinasi manusia. Indikator 3.10.1 yaitu mengidentifikasi strukrur sel saraf, indikator 3.10 .2 yaitu menganalisis proses penghantaran impuls pada sel saraf dan indikator 3.10.3 yaitu menjelaskan perbedaan gerak refleks dengan gerak biasa pada sistem koordinasi manusia.

Tahap perancangan (design), pada tahap ini peneliti melakukan bimbingan dengan dosen untuk menyesuaikan dan menentukan indikator dan materi yang akan dimuat dalam komik. Selanjutnya dilakukan langkah - langkah dalam merancang komik yaitu, menyusun struktur makro, storyboard, penjabaran cerita, penyusunan komik.

Tahap pengembangan (develop) desain komik yang telah jadi selanjutnya memasuki tahap pengembangan yang terdiri dari dua langkah yaitu uji keterbacaan, dan revisi. Uji Keterbacaan dilakukan oleh satu dosen, dua mahasiswa, dan dua siswa SMA yang telah mempelajari materi sistem saraf. Responden memberikan penilaian dengan cara mengisi lembar angket keterbacaan skala 1-5 (5 = sangat setuju, $4=$ setuju, $3=$ ragu-ragu, $2=$ tidak setuju, $1=$ sangat tidak setuju. Hasil uji keterbacaan komik yang diperoleh dari lima responden disajikan dalam Tabel 1.

Tabel 1. Kriteria Interpretasi Data Angket

\begin{tabular}{|l|c|l|}
\hline \multicolumn{1}{|c|}{ Aspek } & $\begin{array}{c}\text { Rata - rata } \\
\text { Tiap Aspek } \\
\mathbf{( \% )}\end{array}$ & \multicolumn{1}{|c|}{ Keterangan } \\
\hline Materi & 90,00 & Hampir seluruh responden \\
\hline Gambar & 86,67 & Hampir seluruh responden \\
\hline Tulisan & 60,00 & Sebagian responden \\
\hline Warna & 80,00 & Hampir seluruh responden \\
\hline Daya tarik & 86,00 & Hampir seluruh responden \\
\hline
\end{tabular}

Dari hasil uji keterbacaan hampir seluruh responden mengatakan materi yang dimuat jelas sehingga mudah dipahami dan mengungkapkan fakta-fakta sehari-hari sehingga mudah dipahami. Sedangkan hampir semua responden mengatakan gambar dan warna yang digunakan dalam komik sesuai, tetapi untuk tulisan yang digunakan hanya sebagian responden yang mengatakan sesuai. Hasil uji keterbacaan ini hampir seluruh responden sebanyak $86,00 \%$ tertarik menggunakan komik sebagai sumber belajar.

Selain hasil uji keterbacaan, responden memberikan masukan terutama tulisan pada komik. Responden menitik beratkan pada beberapa materi yang perlu dijabarkan lebih jauh seperti mekanisme gerak sadar dan gerak refleks, tulisan pada komik yang melibatkan jenis font yang terlihat berdekatan sehingga menyusahkan pembaca, ukuran font yang dapat dibilang cukup kecil, serta ketebalan font, serta 
banyaknya percakapan dalam panel agar tidak terlalu penuh.

Berdasarkan hasil uji keterbacaan yang telah dilakukan terdapat beberapa kritikan dan saran untuk memperbaiki komik tersebut. Hasil perbaikan komik dapat dilihat pada Tabel 2.

Tabel 2. Hasil Perbaikan Komik

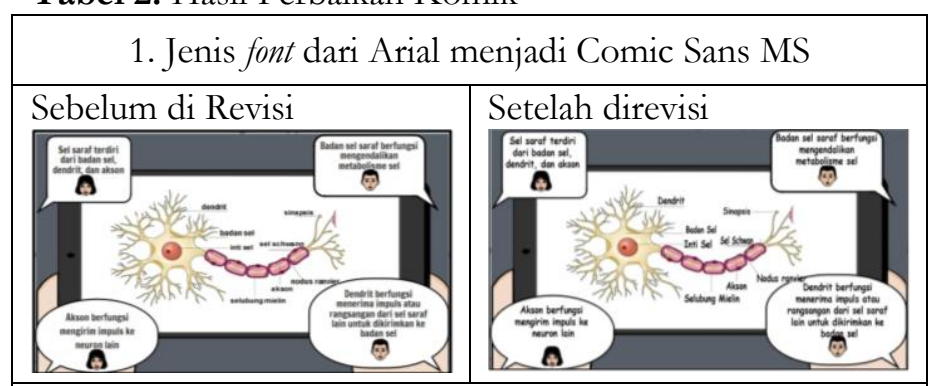

2. Ukuran font dibuat lebih besar pada bagian gambar materi

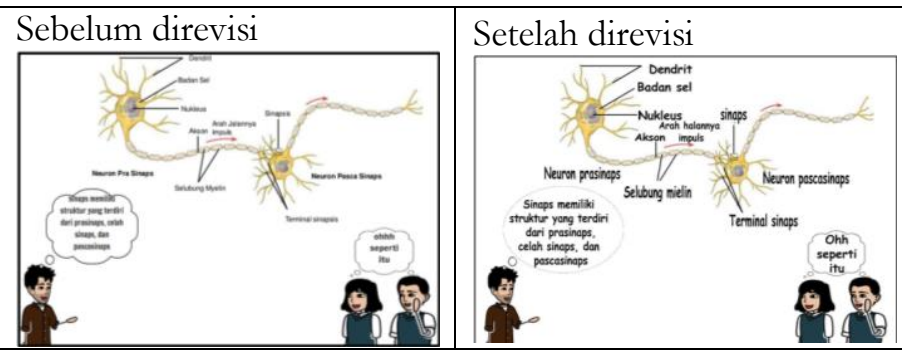

3. Mengurangi balon percakapan dalam satu panel
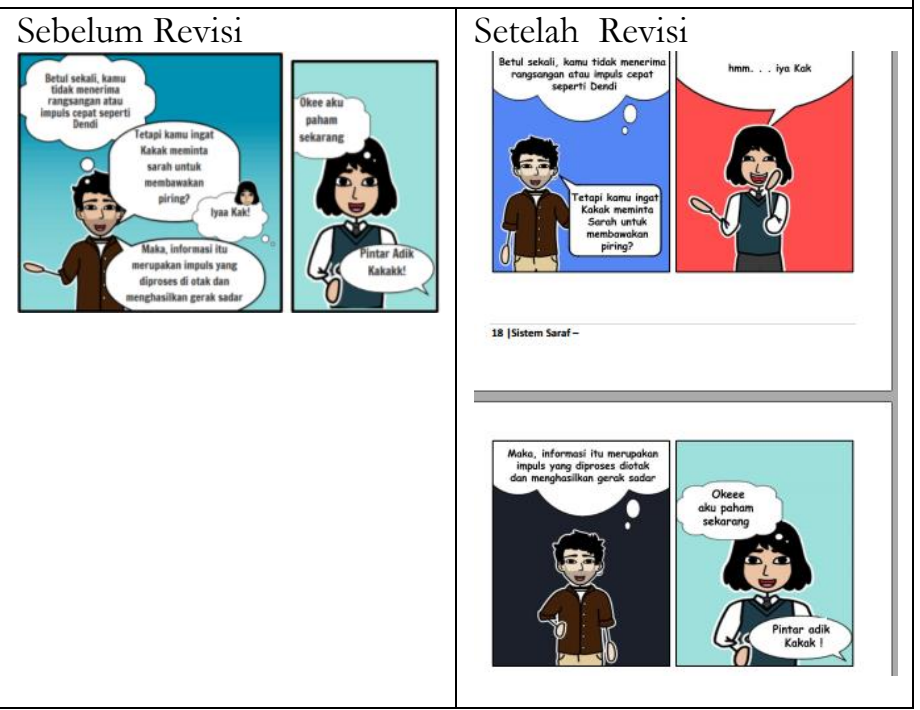

Revisi pada komik sistem saraf ini terdapat pada jenis font, ukuran, dan juga pada balon karakter. Pada jenis font sebelum revisi terlihat lebih ramping dan berdekatan sehingga pembaca akan sulit untuk membacanya, sehingga diganti dengan font yang lebih bulat dan tidak terlalu rapat. Ukuran font sebelumnya terlihat kecil sehingga perlu ukuran yang lebih disesuaikan dengan komik tersebut. Pada setiap panel komik sebelum direvisi lebih padat karena setiap panelnya memuat banyak balon percakapan.

Perbedaan Kemampuan Berpikir Kritis pada Kelas Kontrol dan Eksperimen sebelum dan sesudah pembelajaran
Data hasil kemampuan berpikir kritis melalui tes tertulis berbentuk essai berjumlah 12 soal, soal tersebut mewakili 12 sub indikator dari 5 indikator berpikir kritis. Kelima indikator meliputi: 1). Memberi penjelasan sederhana, 2). Membangun keterampilan dasar, 3). Menyimpulkan, 4). Membuat klarifikasi/ penjelasan lebih lanjut, 5). Strategi dan taktis (Ennis, 1996). Keseluruhan data pretest dan posttest yang didapatkan dalam penelitian berasal dari 2 kelas yaitu kelas eksperimen dan kelas kontrol, setiap kelas berjumlah sama yaitu 30 siswa. Pada penelitian ini sebelum pembelajaran dilakukan pretest untuk mengetahui sejauh mana pengetahuan awal siswa pada kelas kontrol dan kelas eksperimen, kemudian dilakukan posttest setelah pembelajaran untuk mengetahui pengaruh pembelajaran menggunakan komik. Soal Pretest dan Posttest yang diberikan merupakan soal yang sama. Hasil statistika ditampilkan pada tabel 3.

Tabel 3. Rekapitulasi Kemampuan Berpikir Kritis Siswa Melalui pretest antara Kelas Kontrol dan kelas Ekspeimen

\begin{tabular}{|l|c|c|}
\hline \multirow{2}{*}{ Komponen } & \multicolumn{2}{c|}{ Pretest } \\
\cline { 2 - 3 } & Kontrol & Eksperimen \\
\hline Jumlah & 30 & 30 \\
\hline Maksimum & 78,38 & 81,08 \\
\hline Minimum & 56,76 & 51,37 \\
\hline Rata-Rata & 67,97 & 63,15 \\
\hline Standar Devisiasi & 5,57 & 7,35 \\
\hline Sig. & 0,144 & 0,253 \\
\hline Kesimpulan & Normal & Normal \\
\hline Sig. & \multicolumn{2}{|c|}{0,201} \\
\hline Kesimpulan & \multicolumn{2}{|c|}{ Homogen } \\
\hline Sig. & \multicolumn{2}{|c|}{ berbeda signifikan } \\
\hline Kesimpulan & \multicolumn{2}{|c|}{} \\
\hline
\end{tabular}

Hasil dari perhitungan pretest kelas Kontrol dan Eksperimen dilakukan tabulasi terlebih dahulu. Selanjutnya, dilakukan pengujian data pretest pada kelas kontrol dan kelas eksperimen. Rekapitulasi hasil data pretest siswa kelas kontrol dan kelas Eksperimen dapat dilihat pada Tabel 3

Dari hasil uji hipotesis pretest diketahui bahwa kemampuan awal berpikir kritis pada siswa kelas kontrol dan kelas eksperimen berbeda secara signifikan. Oleh karena itu selanjutnya dilakukan perhitungan nilai $\mathrm{N}$-gain. Melalui perhitungan N-gain, dapat diketahui perbedaan peningkatan kemampuan berpikir kritis kelas kontrol dan eksperimen.

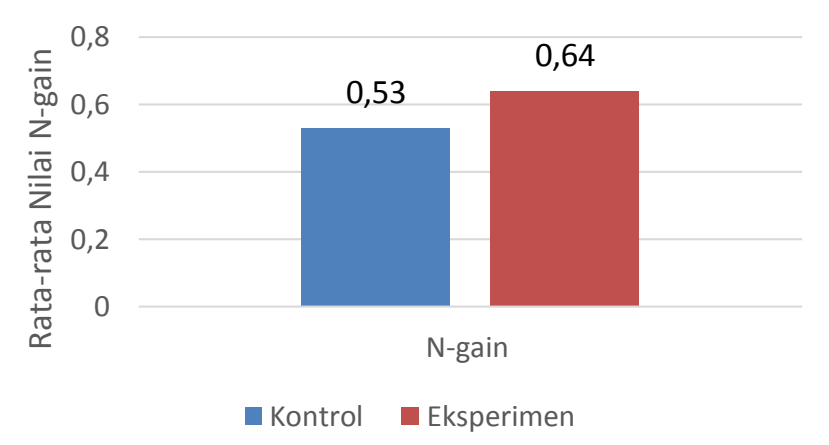

Gambar 1. Nilai Rata-rata N-gain 
Dari hasil analisis nilai kelas eksperimen dan kontrol, rata - rata siswa baik kelas eksperimen maupun kontrol mengalami peningkatan pada kemampuan berpikir kritis ditandai dengan nilai $N$-gain yang termasuk katagori sedang. Tetapi nilai $N$-gain pada kelas eksperimen lebih besar dibandingkan kelas kontrol, sehingga penggunaan komik mampu meningkatkan kemampuan berpikir kritis dibandingkan dengan menggunakan power point. Hasil perhitungan nilai N-gain ditampilkan pada Tabel 4.

Tabel 4. Rekapitulasi Rata-rata Setiap Aspek Berpikir Kritis Siswa Kelas Kontrol dan Kelas Eksperimen

\begin{tabular}{|c|l|c|l|l|l|}
\hline \multirow{2}{*}{ No. } & \multicolumn{1}{|c|}{$\begin{array}{c}\text { Aspek } \\
\text { Indikator }\end{array}$} & $\begin{array}{c}|c| \\
\text { Kelas Kontrol }\end{array}$ & \multicolumn{2}{|c|}{$\begin{array}{c}\text { Kelas } \\
\text { Eksperimen }\end{array}$} \\
\cline { 3 - 6 } & $\begin{array}{c}\text { Rata } \\
\text { N- } \\
\text { gain }\end{array}$ & $\begin{array}{c}\text { Kate- } \\
\text { gori }\end{array}$ & $\begin{array}{c}\text { Rata- } \\
\text { rata } \\
\text { N- } \\
\text { gain }\end{array}$ & $\begin{array}{c}\text { Kate- } \\
\text { gori }\end{array}$ \\
\hline 2. & $\begin{array}{l}\text { Memberi } \\
\text { Penjelasan } \\
\text { Sederhana }\end{array}$ & 0,390 & Sedang & 0,689 & Sedang \\
\hline 3. & $\begin{array}{l}\text { Membangun } \\
\text { keterampilan } \\
\text { Dasar }\end{array}$ & 0,59 & Sedang & 0,54 & Sedang \\
\hline 4. & $\begin{array}{l}\text { Menyimpulkan } \\
\text { Membuat } \\
\text { Penjelas Lebih }\end{array}$ & 0,41 & Sedang & 0,50 & Sedang \\
\hline Lanjut & $\begin{array}{l}\text { Mengatur } \\
\text { Strattegi dan } \\
\text { Taktik }\end{array}$ & 0,50 & Tinggi & 0,85 & Tinggi \\
\hline
\end{tabular}

Berdasarkan Tabel 4 nilai $N$-gain kelas eksperimen lebih besar dibandingkan dengan kelas kontrol. Pada kelas eksperimen dan kelas kontrol, kedua kelas tersebut mengalami peningkatan ditandai dengan nilai $N$-gain yang dikategorikam menjadi tiga kategori yaitu, kategori tinggi, kategori sedang sedang, dan kategori rendah.

Peningkatan kemampuan berpikir kritis ini berkaitan dengan penggunaan komik, karena pada komik yang digunakan siswa dalam pembelajaran sistem saraf memuat indikator dari berpikir kritis. Sedangkan pada kelas kontrol menggunakan power point. Karena dalam penyusunan komik telah disesuaikan dengan dengan materi yang diajarkan disekolah. Sehingga dalam penyampaian materi tidak menyimpang dari standar kompetensi dan kompetensi dasar yang telah disusun. Pada komik tersebut cerita yang diambil berdasarkan cerita sehari-hari sehingga siswa sangat mengenal peristiwa tersebut. Hal tersebut agar siswa mampu mengaitkannya dengan kehidupan sehari - hari siswa dan siswa akan termotivasi dan minat untuk mempelajari materi sistem saraf tersebut.

Komik yang digunakan disusun berdasarkan indikator berpikir kritis yaitu memberi penjelasan sederhana, membangun keterampilan dasar, menyimpulkan, membuat klarifikasi / penjelasan lebih lanjut, strategi dan taktis. Sehingga penerapan representasi visual menggunakan komik dapat meningkatkan kemampuan berikir kritis pada siswa, serta tujuan pembelajan dapat tercapai dengan baik.
Hasil penelitian ini juga sejalan dengan penelitian yang dilakukan Luh \& Ayuning (2018) yang mengatakan adanya peningkatan kemampuan berpikir kritis peserta didik yang mengikuti pembelajaran menggunakan komik dibandingkan dengan peserta didik yang mengikuti pembelajaran dengan menggunakan power point.

Kemampuan pada siswa perlu dikembangkan, karena siswa akan dihadapkan pada berbagai masalah kontekstual yang menuntut kemampuan berpikir dan memecahkan masalah. Kemampuan berpikir kritis siswa penting dikembangkan agar siswa terlatih untuk memecahkan masalah dalam kehidupan nyata dan dalam dunia kerja nantinya. Perlu ditekankan bahwa kemampuan berpikir sangat sesuai dikembangkan untuk siswa. Hal ini berkaitan dengan perkembangan psikologis siswa (Fatimah \& Widiyatmoko, 2015).

Perbedaan Penguasaan Konsep Siswa pada Kelas Eksperimen dan Kelas Kontrol sebelum dan sesudah pembelajaran

Data penguasaan konsep diperoleh melalui pretest dan posttest. Tes berupa pilihan ganda dengan lima pilihan jawaban, butir soal berjumlah 20. Soal yang digunakan pada pretest dan posttest merupakan soal yang sama. Keseluruhan data pretest dan posttest pada kelas eksperimen dan kontrol dengan masing masing siswa berjumlah 30 siswa, dengan jumlah total 60 siswa. Data mentah hasil test, dikonversikan ke dalam sekala 1- 100, lalu dianalisis menggunakan uji statistik. Berdasarkan data hasil penelitian yang didapatkan dicantumkan pada Tabel 5 .

Tabel 5. Rekapitulasi Tingkat Penguasaan Konsep Siswa melalui Pretest antara Kelas Eksperimen dan Kontrol

\begin{tabular}{|c|c|c|c|c|}
\hline \multirow{2}{*}{ Komponen } & \multicolumn{2}{|c|}{ Pretest } & \multicolumn{2}{c|}{ Posttest } \\
\cline { 2 - 5 } & Kontrol & $\begin{array}{c}\text { Ekspe- } \\
\text { rimen }\end{array}$ & Kontrol & $\begin{array}{c}\text { Ekspe- } \\
\text { rimen }\end{array}$ \\
\hline Jumlah & 30 & 30 & 30 & 30 \\
\hline Minimum & 60 & 55 & 70 & 80 \\
\hline Maksimum & 90 & 90 & 100 & 100 \\
\hline Rata-rata & 74,67 & 73,83 & 88,17 & 92,50 \\
\hline $\begin{array}{c}\text { Standar } \\
\text { Devisiasi }\end{array}$ & 8,899 & 8,875 & 8,039 & 5,043 \\
\hline Sig. & 0,100 & 0,240 & 0,024 & 0,010 \\
\hline Kesimpulan & Normal & Normal & $\begin{array}{c}\text { Tidak } \\
\text { Normal }\end{array}$ & $\begin{array}{c}\text { Tidak } \\
\text { Normal }\end{array}$ \\
\hline Sig. & \multicolumn{2}{|c|}{0,767} & \multicolumn{2}{c|}{004} \\
\hline Kesimpulan & \multicolumn{2}{|c|}{ Homogen } & Tidak homogen \\
\hline Sig. & \multicolumn{2}{|c|}{0,718} & H0 ditolak, H1 \\
\hline Kesimpulan & \multicolumn{2}{|c|}{ ditolak, H0 } \\
diterima & \multicolumn{2}{c|}{} \\
\hline
\end{tabular}

Hasil uji t menunjukan adanya perbedaan nyata antara kelas eksperimen dan kelas kontrol. Sehingga dari data analisis pretest dan posttest diketahui adanya penggaruh penggunaan komik terhadap penguasaan konsep siswa pada materi sistem saraf. Dari hasil uji $\mathrm{t}$ nilai rata-rata posttest penguasaan konsep terdapat perbedaan nyata. Sehingga diperlukan perhitungan nilai $N$-gain. Melalui perhitungan $N$-gain, dapat diketahui perbedaan peningkatan penguasaan konsep siswa pada kelas kontrol dan kelas eksperimen. 
Pengaruh penggunaan komik terhadap penguasaan konsep dilihat dari pengkategorian nilai $N$-gain pada kelas kontrol dan eksperimen.

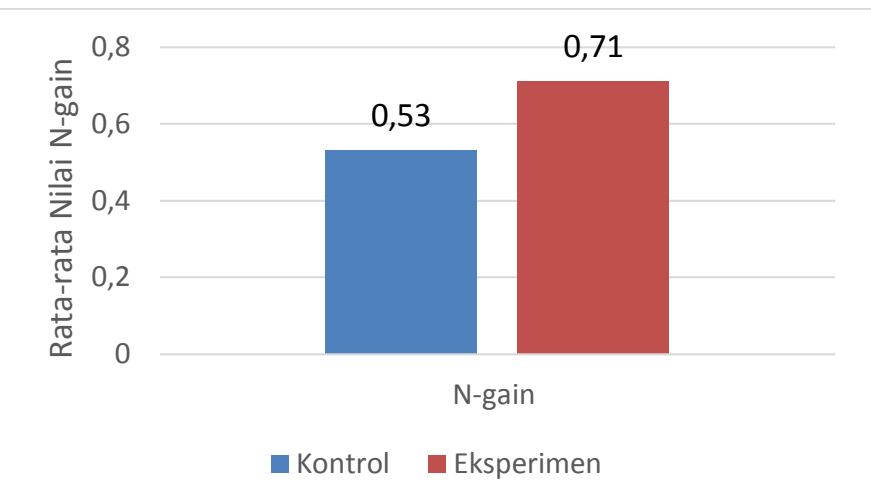

Gambar 2. Rata-Rata Nilai N-gain Penguasaan Konsep

Gambar 2. dapat dilihat nilai rata-rata N-gain penguasaan konsep kelas eksperimen lebih besar dibandingkan dengan kelas kontrol. Pada kelas eksperimen rata-rata nilia $\mathrm{N}$-gain sebesar 0,71 sedangkan pada kelas kontrol sebesar 0,53. Pada kelas eksperimen merupakan kategori tinggi karena nilai $\mathrm{N}$-gain lebih dari 0,7, sedangkan pada kelas kontrol termasuk kategori sedang.

Hal ini membuktikan bahwa terdapat perbedaan perubahan penguasaan konsep setelah melakukan pembelajaran baik kelas kontrol maupun kelas eksperimen. Berdasarkan hasil penelitian diketahui bahwa penggunaan komik pada kelas eksperimen memiliki pengaruh lebih besar terhadap penguasaan konsep pada siswa pada materi sistem saraf. Hal ini berkaitan dengan pengguaan komik sebagai salah satu respresentasi berupa visual. Sehingga siswa lebih mudah untuk memahami materi dibuktikan dengan adanya kenaikan penguasaan konsep siswa.

Berdasarkan Gambar 2. dapat dilihat nilai N-gain pada kelas eksperimen lebih besar di bandingkan dengan kelas kontrol. Hal ini karena pembelajaran menggunakan komik baru diterapkan, sehingga siswa mendapatkan pengalaman menggunakan sumber belajar berbeda. Sedangkan kelas kontrol belajar menggunakan power point. Penelitian ini sejalan dengan penelitian Wahyuningsih (2012) yang menunjukan bahwa komik bergambar materi sistem saraf untuk pembelajaran dapat meningkatkan hasil belajar siswa dengan N-gain sedang. Serta penelitian yang dilakukan oleh Suparmi (2018) mengemukakan bahwa penggunaan komik dapt meningkatkan pemahaman siswa pada konsep yang sedang dipelajari. Komik juga merupakan salah satu sumber belajar yang sering digunakan karena mampu meningkatkan motivasi siswa ditandai dengan meningkatnya nilai hasil belajar. Komik merupakan sumber belajar alternatif yang tepat untuk pembelajaran, karena keterlibatan emosi pembacanya akan sangat mempengaruhi memori dan daya ingat akan materi pelajaran yang di dapat (Mediawati, 2011).

Penggunaan komik perlu dilakukan karena berdasarkan penelitian yang dilakukan Suparmi (2018) menunjukan bahwa: a) Penggunaan komik dapat meningkatkan hasil belajar siswa; b) Penggunaan komik dapat meningkatkan kualitas dan efisiensi pembelajaran; c) Penggunaan komik di sekolah dapat mengurangi kebosanan pada saat proses pembelajaran.

Komik sebagai media visual dapat digunakan sebagai sumber belajar yang mampu menyampaikan informasi secara efektif dan efisien. Komik dapat menjadi pilihan sebagai sumber belajar karena adanya kecenderungan banyak siswa lebih menyenangi bacaan seperti komik dibandingkan dengan buku pelajaran (Waluyanto, 2005).

Science comic efektif untuk meyampaikan IPA secara sederhana dan mudah. Namun, science comic dalam pembelajaran IPA di SMP masih jarang digunakan. Pengembangan science comic dapat membantu siswa dalam memahami materi IPA secara mudah dengan tampilan yang menghibur (Fatimah \& Widiyatmoko, 2015).

\section{Tanggapan Siswa Terkait Penggunaan Komik pada Materi Sistem Saraf pada Kelas Eksperimen}

Respon siswa terhadap pembelajaran dengan menggunakan komik diukur menggunakan angket respon siswa menggunakan skala lima. Angket berjumlah 11 pertanyaan dengan skala 1-5 yang harus dijawab oleh siswa setelah dilaksanakannya pembelajaran menggunakan komik.

Pembelajaran representasi menggunakan komik menjadi pengalaman baru bagi hampir seluruh responden, sebelumnya menggunakan power point dan text book, sehingga komik menjadi suatu yang baru untuk pembelajaran biologi. Hal ini ditunjukkan dengan persentase sebesar 82,67\%. Pada pembelajaran menggunakan representasi menggunakan komik ini, siswa merasa tertarik dalam pembelajaran ini dilihat dari persentase respon siswa yang tinggi yaitu 83,33\%. Hampir seluruh responden sebanyak $84,47 \%$ mengalami ketertarikan dalam penggunaan komik ini berkaitan dengan materi yang disajikan dalam bentuk gambar dan cerita yang dapat memudahkan siswa dalam memahami materi. Selain itu hampir seluruh responden tertarik pada tampilan gambar dan alur ceritanya yang mudah diikuti, hal ini dilihat dari persentase respon siswa yang cukup tinggi $89,33 \%$. Rangkaian cerita pada komik pun mudah dipahami dan mudah di eja, hal ini dibuktikan dari hasil respon siswa sebesar 84,67\%. Ketertarikan siswa pada pembelajaran menggunakan komik juga sesuai dengan penelitian Purwanto (2013) yang menyatakan bahwa siswa tertarik untuk menggunakan komik dalam pembelajaran IPA pada tema yang lain. Menurut Riduwan (2010) penggunaan komik sangat layak digunakan oleh siswa. Hal itu sesuai dengan pernyataan (Sudjana \& Rivai, 2001) yang menyatakan bahwa peranan pokok komik sebagai sumber belajar mampu menciptakan minat siswa. Komik merupakan suatu jembatan untuk menumbuhkan minat baca.

Penerapan representasi menggunakan komik ini mampu memberikan aplikasi atau implementasi dari penggunaan komik. Hal ini terlihat dari hampir seluruh responden merasakan adanya kenaikan kemampuan berpikir kritis, bertambahnya pengetahuan mengenai sistem saraf, serta menemukan konsep baru mengenai sistem saraf hal ini dilihat dari presentase respon siswa sebesar $80,00 \%$ pada peningkatan berpikir kritis setelah pembelajaran menggunakan komik. Serta pembelajaran menggunakan 
komik ini dapat diaplikasikan di sekolah, berdasarkan respon siswa yang tinggi yaitu 90,00 \%, yang artinya hampir seluruh responden menyatakan demikian. Dilihat dari kemampuan berpikir kritis dan penguasaan konsep siwa mengalami kenaikan setelah pembelajaran menggunakan komik. Hal ini sejalan dengan penelitian yang dilakukan oleh Suparmi (2018) menyatakan bahwa penggunaan komik sebagai sumber belajar sudah mulai dari tingkat Taman Kanak Kanak sampai tingkat SMA.

Pengunaan pembelajaran menggunakan komik tetap memiliki hambatan terkait biaya dan kesulitan. Sebagian responden menyatakan adanya hambatan berupa biaya mengakses komik pembelajaran sebesar 58,67\% dan kesulitan mengakses komik sebesar 48,67\%. Pembelajaran menggunakan komik ini dapat dilakukan secara online, komik dikirimkan melalui google classroom sehingga tidak memerlukan biaya yang banyak. Penggunaan komik secara online tidak terdapat banyak kesulitan, kesulitan hanya terkait bentuk format file yang tidak semua HP siswa dapat mengakses. Hambatan dalam pembelajaran menggunakan komik dikatakan juga dalam penelitian oleh Purwanto (2013) yang menyatakan bahwa ketidakmampuan siswa dalam memahami isi materi dalam komik yang telah disusun dan diseseuaikan dengan indikator dan tujuan pembelajaran. Sehingga dalam kegiatan belajar mengajar, guru tetap menjadi komponen yang paling utama sedangkan komik hanya memiliki peran sebagai alternatif bahan ajar. Dua aspek yang paling menonjol dalam kegiatan belajar mengajar yaitu metode mengajar dan bahan ajar yang dirancang.

Berhasarkan hasil respon siswa mengenai penerapan representasi menggunakan komik adalah siswa dapat menggunakan komik pembelajaran ini dengan baik, serta tertarik untuk menggunakannya. Walaupun terdapat hambatan dan kesulitan, sumber belajar komik ini mampu meningkatkan hasil belajaran bagi siswa.

\section{SIMPULAN}

Tahapan pembuatan komik dilakukan dengan tiga tahap, yaitu pendefinisian, perancangan, dan pengembangan. Pada pembuatan komik harus diperhatikan karakteristik komik seperti panel, balon percakapan, tokoh, font, ukuran font, serta pewarnaan komik. Dengan representasi visual menggunakan komik, terjadi perubahan kemampuan berpikir kritis. Hal ini dilihat dari nilai $\mathrm{N}$-gain kelas eksperimen lebih besar dibandingkan dengan kelas kontrol. Penerapan representasi visual menggunakan komik juga terjadi perubahan terhadap kemampuan penguasaan konsep. Hal ini dilihat dari nilai $\mathrm{N}$-gain kelas eksperimen yang lebih besar dibandingkan dengan kelas kontrol. Berdasarkan hitungan angket respon siswa terhadap pembelajaran menggunakan representasi menggunakan komik yang diberikan kepada siswa kelas eksperimen setelah pembelajaran, pada umumnya menunjukkan hasil yang positif terhadap penggunaan komik. Pernyataan yang diberikan terkait kegiatan belajar, ketertarikan, hambatan, serta aplikasi dan implementasi pembelajaran menggunakan representasi visual berupa komik.

\section{REFERENSI}

Ennis, R. H. (1996). Critical Thinking Dispositions : Their Nature and Assessability. Informal logic 18(2), 165182.

Fatimah, F., \& Widiyatmoko, A. (2015). Pengembangan science comic berbasis problem based. Unnes Science Education Journal, 4(1), 700-710.

Mardiyah, D. A., \& Surakusuma, W. (2016). Pengembangan media komik sebagai media pembelajaran pada konsep pencemaran lingkungan. PROSIDING SNIPS 2016, 239-247.

Mediawati, E. (2011). Pembelajaran akuntansi keuangan melalui media komik untuk meningkatkan prestasi mahasiswa. Jurnal Penelitian Pendidikan, 12(1), 61-68.

Purwanto, D. (2013). Pengembangan media komik ipa terpadu tema pencemaran air. Jurnal Pendidikan Sains e-Pensa, 1(1), 71-76.

Riduwan. (2010). Skala Pengukuran Variabel Variabel Penelitian. Bandung: Alfabeta.

Sudjana \& Rivai. (2001). Media Pengajaran. Jakarta: Kencana Predana Media.

Suparmi. (2018). Penggunaan media komik dalam pembelajaran ipa di sekolah. Journal of Natural Science and integration, (1), 62-68.

Tiemensma, L. (2009, 23-27 Agustus). Visual Literacy To Comics Or Not To Comics [Paper Presentation] World Library And Information Congress: 75th IFLA General Conference And Council, Milan, IT. https://www.ifla.org/past-wlic/2009/94tiemensma-en.pdf

Wahyuningsih, A. N. (2012). Pengembangan media komik bergambar materi sistem saraf untuk pembelajaran yang menggunakan strategi PQ4R. Journal of Innovative Science Education, 1(1).

Waluyanto, H. D. (2005). Komik sebagai media komunikasi visual pembelajaran. Nirmana, 7(1), 4555 .

Conflict of Interest Statement

The author(s) declare that the research was conducted in the absence of any commercial or financial relationships that could be construed as a potential conflict of interest.

How to Cite

Rahmi, N. N., Purwianingsih, W., \& Sriyati, S. (2021). Penerapan representasi visual menggunakan komik sebagai upaya meningkatkan kemampuan berpikir kritis dan penguasaan konsep siswa pada materi sistem saraf . Assimilation: Indonesian Journal of Biology Education, 4(2), 77-82. 